\title{
KONSEP HIMPUNAN DAN DIAGRAM VENN PADA SMP NEGERI 07 BENGKULU BERBASIS MULTIMEDIA
}

\author{
Mahdarena, Siswanto, Sapri \\ Program Studi Teknik Informatika Fakultas Ilmu Komputer Universitas Dehasen Bengkulu \\ Jl. Meranti Raya No. 32 Kota Bengkulu 38228 Telp. (0736) 22027, 26957 Fax. (0736) 341139
}

\begin{abstract}
One of the competencies that must be mastered students currently studying mathematics in junior high school (SMP) and is listed in the RPP (lesson plan) made by the teacher of junior high school mathematics is able to complete the concept of sets and Venn diagrams. In the current study the concept of sets and Venn diagrams, mastery of competencies was very important because it will be the main prerequisite when students learn the concept of sets and Venn diagrams on the next steps. Difficulties faced by teachers of mathematics and junior high school students in the form of low level of understanding of the students about the concepts related to the concept of sets and Venn diagrams and low skills in mennyelesaikan concept of sets and Venn diagrams. With such a reality, the use of instructional media using Macromedia Flash is one of supporting the achievement of an effective learning objectives and easy to understand The concept of Association and Venn Diagram multimedia applications on SMP 07 Bengkulu generated based Multimedia can provide convenience to the teachers of secondary school (SMP) 07 State of Bengkulu in providing the subject matter of the concept of Association and Venn Diagrams in SMP Negeri 07 Bengkulu based Multimedia.
\end{abstract}

Keywords: Macromedia Flash, Concepts Association and the Venn Diagram, SMP 07 Bengkulu based Multimedia

INTISARI

Salah satu kompetensi yang harus dikuasai siswa saat belajar matematika di Sekolah Menengah Pertama (SMP) dan tercantum dalam RPP (rencana pelaksanaan pembelajaran) yang dibuat oleh guru mata pelajaran matematika SMP adalah mampu menyelesaikan konsep himpunan dan diagram venn. Di saat belajar konsep himpunan dan diagram venn, penguasaan kompetensi itu sangat penting karena akan menjadi prasyarat utama saat siswa belajar konsep himpunan dan diagram venn pada tahap-tahap berikutnya. Kesulitan yang dihadapi oleh guru matematika dan siswa SMP berupa pemahaman yang rendah dari siswa tentang konsep-konsep yang terkait dengan konsep himpunan dan diagram venn dan skill yang rendah dalam mennyelesaikan konsep himpunan dan diagram venn. Dengan kenyataan seperti itu maka penggunaan media pembelajaran menggunakan Macromedia Flash merupakan salah satu penunjang tercapainya suatu tujuan pembelajaran yang efektif dan mudah dipahami Aplikasi multimedia Konsep Himpunan dan Diagram Venn pada SMP Negeri 07 Bengkulu berbasis Multimedia yang dihasilkan dapat memberikan kemudahan kepada para guru Sekolah Menengah Pertama (SMP) Negeri 07 Kota Bengkulu dalam memberikan materi pelajaran tentang Konsep Himpunan dan Diagram Venn pada SMP Negeri 07 Bengkulu berbasis Multimedia.

Kata Kunci: Macromedia Flash, Konsep Himpunan dan Diagram Venn, SMP Negeri 07 Bengkulu berbasis Multimedia

\section{PENDAHULUAN}

Keberadaan komputer bukan merupakan hal yang baru lagi dalam era Globalisasi masa kini, karena hampir setiap instansi baik itu pemerintahan maupun swasta sudah mengguakan komputer dalam menglolah data-data pekerjaaan, bahkan sudah termodifikasi dalam beberapa bentuk program softwere yang sesuai dengan kebutuhan. Hal ini menunjukan bahwa penerapan ilmu pengetahuan dan teknologi (IPTEK) sangat bermanfaat dan sangat berpengaruh pada suatu tataan kerja yang

Salah satu kompetensi yang harus dikuasai siswa saat belajar matematika di Sekolah Menengah Pertama (SMP) dan tercantum dalam RPP (rencana pelaksanaan pembelajaran) yang dibuat oleh guru mata pelajaran matematika SMP adalah mampu menyelesaikan konsep himpunan dan diagram venn. Di saat belajar konsep himpunan dan diagram venn, penguasaan kompetensi itu sangat penting karena akan menjadi prasyarat utama saat siswa belajar konsep himpunan dan diagram venn pada tahap-tahap berikutnya.

Kemampuan mengoperasikan konsep himpunan dan diagram venn yang baik tidak dapat dipisahkan dari pemahaman yang baik tentang konsep-konsep yang terkait, misalnya pemahaman tentang lambang konsep himpunan dan diagram venn berupa suku, faktor, variabel, konstanta, koefisien, dan lainnya. Dengan pemahaman yang baik terhadap konsepkonsep itu diharapkan kompetensi menyelesaikan konsep himpunan dan diagram venn akan dikuasai dengan baik. Untuk itu pembelajaran perlu dikelola dengan memperhatikan azas-azas didaktik metodik agar berlangsung efektif.

Kesulitan yang dihadapi oleh guru matematika dan siswa SMP berupa pemahaman yang rendah dari siswa tentang konsep-konsep yang terkait dengan konsep himpunan dan diagram venn dan skill yang 
rendah dalam mennyelesaikan konsep himpunan dan diagram venn. Pada pihak guru terdapat keluhankeluhan yang pada intinya adalah sulit menemukan cara untuk membuat siswa mudah memahami konsep-konsep yang terkait dengan konsep himpunan dan diagram venn dan cara-cara praktis untuk menerampilkan siswa dalam menyelesaikan konsep himpunan dan diagram venn.

Dengan kenyataan seperti itu maka penggunaan media pembelajaran menggunakan Macromedia Flash merupakan salah satu penunjang tercapainya suatu tujuan pembelajaran yang efektif dan mudah dipahami

Di SMP 7 Kota Bengkulu, metode pembelajaran konsep himpunan dan diagram venn masih disampaikan secara manual. Oleh karena itu dibutuhkan sebuah media pembelajaran himpunan dan diagram venn agar proses belajar mengajar lebih menyenangkan, efektif dan efisien.

\section{TINJAUAN PUTAKA}

\section{A) Pengertian Konsep}

Secara umum, konsep dapat diartikan sebagai suatu representasi abstrak dan umum tentang sesuatu. Karena sifatnya yang abstrak dan umum, maka konsep merupakan suatu hal yang bersifat mental. Representasi sesuatu itu terjadi dalam pikiran. Sebuah konsep mempunyai rujukan pada kenyataan. Ada juga yang mengartikan bahwa, pengertian konsep adalah suatu medium yang menguhubungkan subjek penahu dan objek yang diketahui, pikiran, dan kenyataan. Konsep termasuk dalam jenis medium in quo. Dalam sebuah konsep, kita mengenal, memahami, dan menyebut objek yang kita ketahui. Kekhususan dari medium in quo adalah walaupun dalam pengenalan akan objek tertentu, yang langsung kita sadari bukan konsepnya tetapi objek fisik itu sendiru, tetapi dalam suatu refleksi, konsep sendiri dapat menjadi objek perhatian dan kesadaran.

Pengertian konsep dapat dimengerti dari sisi subjek maupun dari sisi objek. Dari sisi subjek, suatu konsep adalah kegiatan merumuskan dalam pikiran atau menggolong-golongkan. Sedangkan, dari sisi objek, konsep adalah isi kegiatan tersebut, artinya, apa makna konsep itu. Sebagai sesuatu yang bersifat umum, konsep adalah suatu yang bersifat universal. Konsep universal dapat bersifat langsung, bisa juga tidak langsung. Konsep universal langsung adalah konsep yang bisa dipredikasikan secara univok (secara persis sama) dan secara distributif (satu per satu) pada banyak individu.

\section{B) Pengertian Flash 8.0}

Menurut Sudirman (2011:3) Macromedia Flash 8 merupakan software milik perusahaan Macromedia dan merupakan pengembangan dari Flash versi sebelumnya. Macromedia Flash sendiri merupakan sebuah aplikasi standar authoring tool professional yang digunakan untuk membuat animasi yang sangat menakjubkan untuk keperluan pembangunan situs web yang interaktif dan dinamis. Selain itu, aplikasi ini juga dapat digunakan untuk membuat animasi logo, movie, game, pembuatan navigasi pada situs web, banner, tombol animasi, menu interaktif, interaktif form isian, e-card, screen saver dan pembuatan keseluruhan isi situs web atau pembuatan aplikasi-aplikasi web lainnya.

Movie-movie Flash 8 memiliki ukuran file yang kecil sehingga dapat di download secara cepat dan dapat ditampilkan dengan ukuran layar yang dapat disesuaikan dengan keinginan. Aplikasi Flash 8 merupakan sebuah standar aplikasi industri perancangan animasi web yang tak tertandingi dengan peningkatan pengaturan dan perluasan kemampuan integrasi yang lebih tinggi lagi.

Area kerja Flash 8 dirancang secara khusus agar ruang kerja yang digunakan dapat diatur dan lebih mudah dipahami oleh pemakai pemula maupun para desainer Flash yang telah berpengalaman. Macromedia Flash 8 adalah program yang cukup komplek sehingga tidak mungkin untuk menjabarkannya secara lengkap. Pada makalah ini hanya akan diberikan sebagian pengertian dan fungsifungsi dasar dalam Macromedia Flash 8.

Menurut Catatan sialik (2013) Macromedia Flash 8 adalah suatu program yang dapat digunakan untuk membuat suatu karya animasi, tidak sedikit para animator membuat beragam animasi, seperti interaktif maupun non interaktif.

\section{C) Konsep Dasar Animasi}

Konsep dasar dari sebuah animasi terdiri dari beberapa bentuk, diantaranya movie clip, object, teks, sound dan symbol.

Animasi yang dibuat dalam flash sering disebut dengan Movie. Dalam sebuah bentuk animasi, pendesainan haruslah mengatur jalan cerita dari animasi tersebut, membuat beberapa contoh dan rangkaiannya menjadi suatu bagian yang mempunya makna. Suatu Movie yang terdiri dari beberapa animasi disebut Movie Clip, yang dapat dijalankan dalam suatu Scene dengan banyak Layer.

Dalam membuat animasi, maka terlebih dahulu harus dibuat sebuah objek (bagian yang akan ditampilkan). Setelah itu mangatur gerakan-gerakan 
dari objek tersebut. Selain itu Flash juga menyediakan Tool-tool untuk membuat objek sederhana seperti Garis, Lingkaran dan bentuk lainnya.

Bagian Toolbox disediakan fasilitas untuk membaut teks yang nantinya teks ini bisa dijadikan sebuah animasi. Penulisannya sama seperti aplikasi lain yang ada pada windows. Terdapat pula jenis huruf, ukuran huruf, sama halnya seperti aplikasi Microsoft Office.

Sound adalah asalah satu fasilitas yang dapat kita gunakan untuk menambah daya tarik sendiri animasi yang kita buat, nantinya setiap animasi yang muncul akan kita iringi dengan suara-suara yang mendukung tampilan tersebut.

Dalam Macromedia flash 8, ada beberaa symbol yang disediakan yaitu, Button, movieclip dan graphic.

\section{D) Mengenal File Audio}

Dalam menjalankan sebuah movie clip sering diikut dengan adanya sound. Dengan adanya sound maka lengkaplah Macromedia sebagai suatu software animasi yang mengombinasikan animasi teks, grafik, dan suara sehingga program yang dihasilkan akan menjadi lebih menarik dan interaktif dengan pemakai. Pemakai tidak hanya melihat animasi yang berjalan pada program yang dibuat akan tetapi melihat bagaimana penjelasan-penjelasan dari program yang dibuat dalam bentuk suara.

Beberapa tipe dari file audio yang dapat dijalankan dalam program Macromedia Flash, yaitu file extension.WAV dan MP3. Untuk memasukkan file ini ke dalam program yang akan dibuat terlebih dahulu dengan mengimport file tersebut ke dalam library.

Menurut Kusnadi (2005:56) Macromedia Flash 8 merupakan salah satu Software aplikasi design grafis yang sangat popular saat ini terutama untuk membuat aplikasi yang berbasis animasi. Kelebihan dari aplikasi ini adalah sangat mudah untuk dipelajari dan difahami.

Dari berbagai media informasi, multimedia memilki suatu kelebihan tersendiri yang tidak dapat digantikan oleh penyajian media informasi lainnya. Kelebihan dari multimedia adalah menarik indra dan menarik minat, karena merupakan gabungan antara pandangan,suara dan gerakan.

Lembaga riset dan penerbitan komputer yaitu Computer Technology Research (CTR) menyatakan bahwa orang hanya mampu mengingat $20 \%$ dari yang dilihat dan $30 \%$ dari yang didengar. Tetapi orang mengingat $50 \%$ dari yang dilihat dan didengar dan $80 \%$ dari yang dilihat, didengar dan dilakukan sekaligus.

\section{E) Konsep Himpunan dan Diagram Venn}

Berdasarkan Kurikulum Tingkat Satuan Pendidikan (KTSP). Materi himpunan dan diagrm venn yang diajarkan di Sekolah Menengah Pertama (SMP) 7 Kota Bengkulu aadalah sebagai berikut:

1) Memahami pengertian dan notasi himpunan serta penyajiannya

2) Memahami konsep himpunan bagian

3) Melakukan operasi irisan, gabungan dan komplemen

4) Menyajikan himpunan dengan diagram venn

5) Menggunakan konsep himpunan pemecahan masalah

\section{A) Metode Penelitian}

Dalam melakukan penelitian ini, penulis menggunakan metode pengembangan sistem. Dimana dengan melakukan dalam tahapan pengembangan sistem sebagai berikut :

1) Meneliti dan mengumpulkan data-data yang diperlukan dalam pembuatan media pembelajaran.

2) Membuat rancangan media pembelajaran.

3) Membuat media pembelajaran menggunakan Macromedia Flash Pro 8.0

\section{B) Software dan Hardware}

Dalam melakukan penelitian ini, software dan hardware yang dibutuhkan adalah sebagai berikut :

1) Komputer Processor Intel Pentium IV 3 Ghz.

2) Hardisk $80 \mathrm{~GB}$

3) RAM 256 GB

4) Monitor SVGA

5) Keyboard 101/102 or Microsoft Natural PS/2 Keyboard

6) Mouse BenQ M106-P

7) Printer Canon 1800

8) Sistem Operasi Windows XP

9) Aplikasi Macromedia Flash 8.0

10) Aplikasi Photoshop

\section{C) Perancangan Sistem}

\section{1) Analisa Sistem Aktual}

Dengan berdasarkan pengamatan awal pada SMP 7 Kota Bengkulu, kelemahan-kelemahan penggunaan komputer dalam pembelajaran sebenarnya dapat diatasi walaupun tidak seluruhnya, jika program pembelajaran menggunakan komputer dibuat interaktif. Penerapan teknologi komputer mendorong 
proses pembelajaran ke arah "individual learning", di mana posisi guru bergeser dari instruktur tradisional. Selain itu, pembelajaran individu mendorong pembelajar ke arah belajar aktif, kreatif dan interaktif. Dengan demikian maka perolehan pengetahuan pembelajar tidak lagi bersumber dari transfer ilmu oleh guru, melainkan melalui kegiatan membangun ilmu oleh pembelajar itu sendiri. Pembelajaran dilakukan dengan melihat mata pelajaran dibuku dan mencatat materi yang dijelaskan dipapan tulis. Dengan cara yang demikian tersebut ternyata masih banyak memiliki kelemahan-kelemahan yang mana siswa masih belum mampu memahami secara cepat dan benar.

Seiring dengan kemajuan teknologi seperti sekarang ini yaitu khususnya dalam bidang Teknologi, kebutuhan akan perananan komputer dan software begitu dibutuhkan di 7 Kota Bengkulu, karena akan memudahkan Guru dalam penyampaian materi yang diajarkan.

\section{2) Analisa Sistem Baru}

Berdasarkan dari hasil penelitian di SMP 7 Kota Bengkulu sebelumnya, penulis akan membangun Program yang berbasis Media Pembelajaran interaktif yang memiliki kriteria Program yang dibangun merupakan suatu media pembelajaran yang dilengkapi dengan gambar animasi dan audio dan Program yang dibangun disesuaikan dengan buku atau bahan ajar yang digunakan di SMP 7 Kota Bengkulu.

\section{Rancangan Struktur Menu}

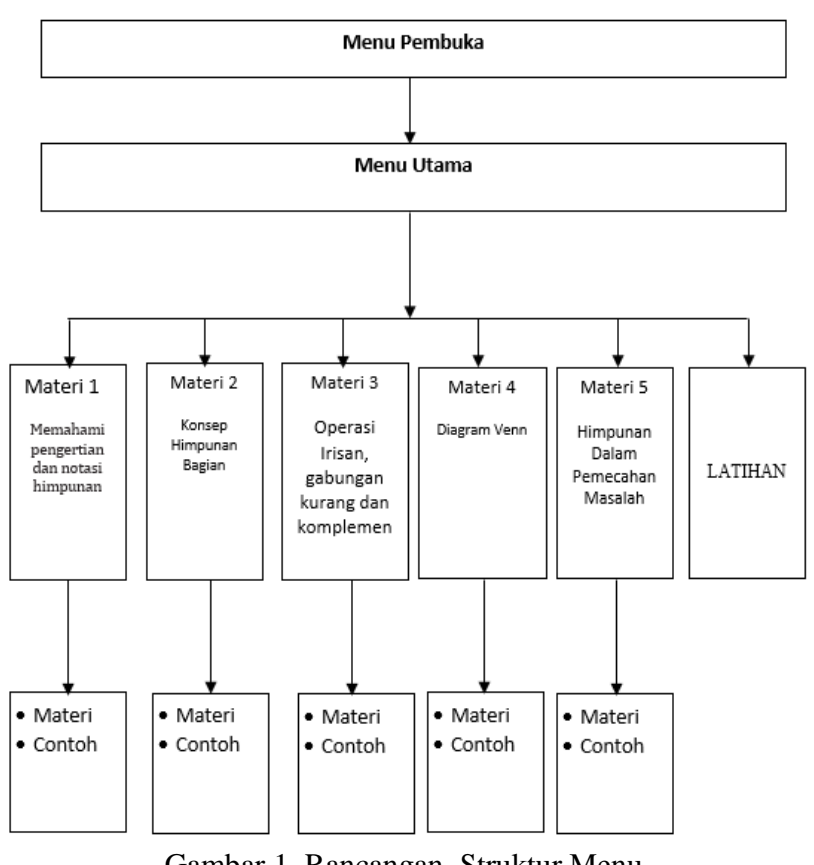

Gambar 1. Rancangan Struktur Menu

\section{Rancangan Menu Pembuka}

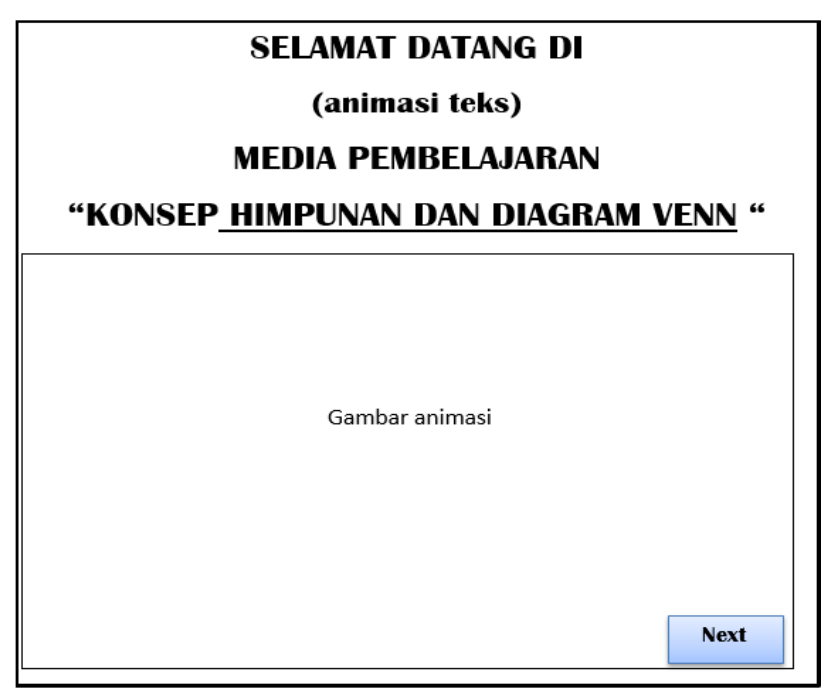

Gambar 2. Rancangan Menu Pembuka

Keterangan:

a) Animasi Teks :

b) Animasi Ucapan Selamat datang di Media Pembelajaran "Himpunan dan diagram venn"

c) Animasi Gambar :

d) Berisikan animasi gambar gedung sekolah.

e) Teks :

f) Berisikan Teks yang menginformasikan tujuan pembelajaran dari materi "Himpunan dan diagram venn".

g) Next:

h) Tombol Next merupakan tombol yang untuk lanjut ke proses akses menu utama.

\section{Rancangan Menu Utama}

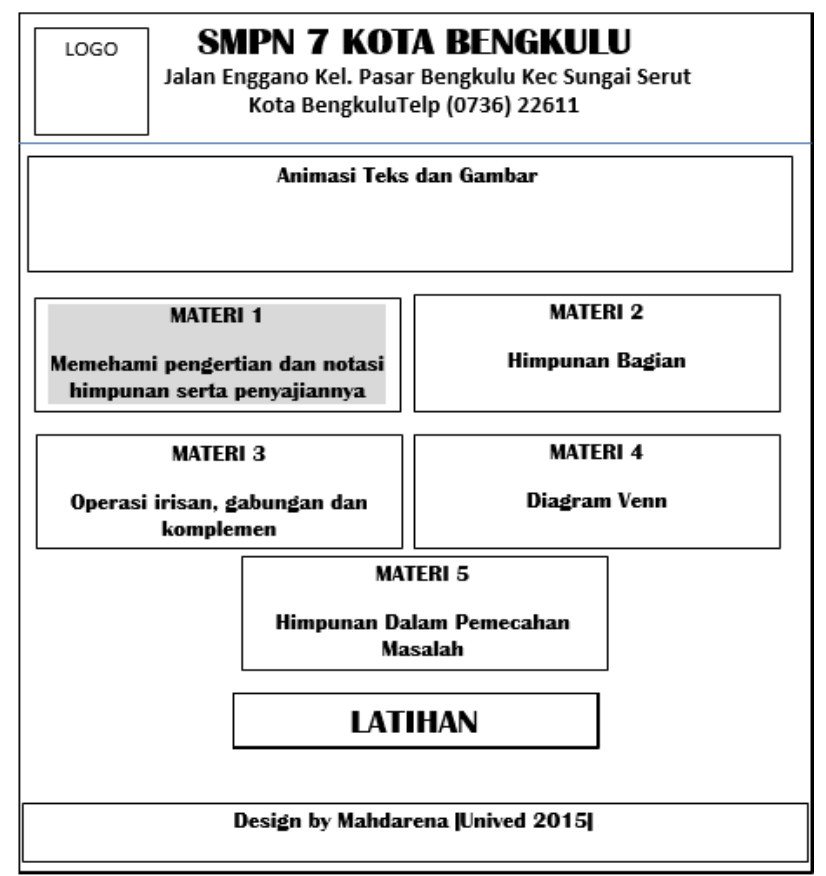

Gambar 3. Rancangan Menu Utama 


\section{Rancangan Menu Materi 1}

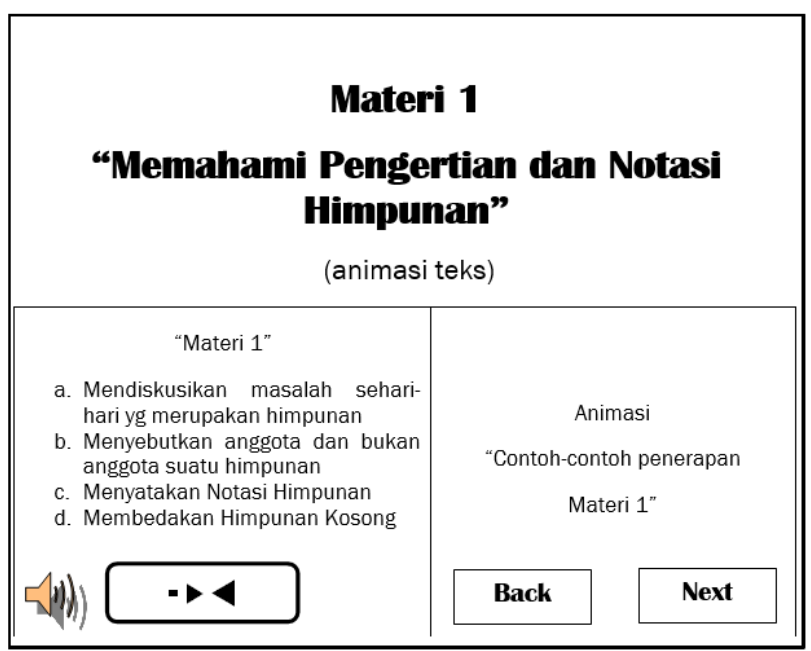

Gambar 4. Rancangan Menu Materi 1

Keterangan:

a) Animasi Teks : Animasi teks yang berisikan teks Materi 1 Notasi Himpunan

b) Materi $1:$ Berisikan teori-teori tentang notasi himpunan dalam kehidupan sehari-hari.

c) Tombol back: Merupakan tombol untuk kembali akses menu utama

d) Tombol volume : Merupakan Tombol untuk suara.

e) Next : Materi selanjutnya

Rancangan Menu Materi 2

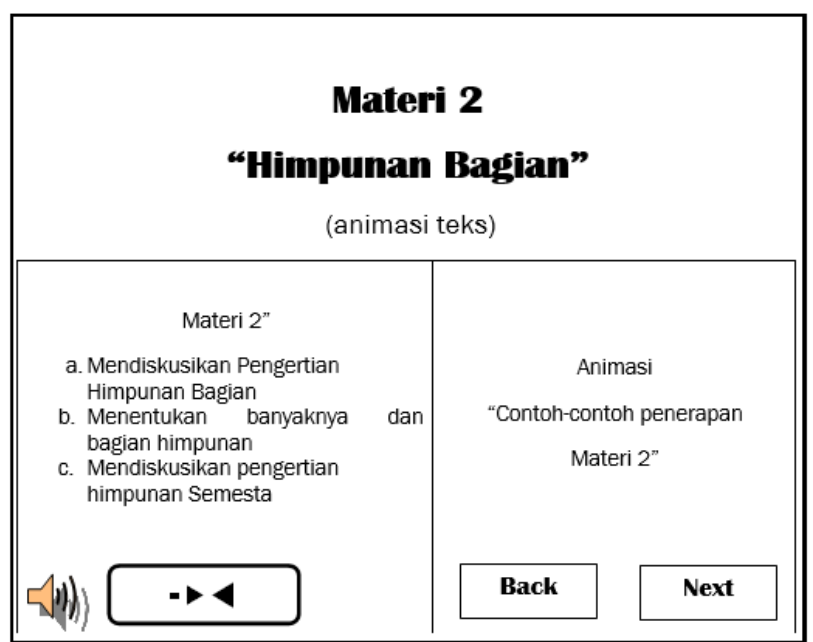

Gambar 5. Rancangan Menu Materi 2

Keterangan:

a) Animasi Teks : Animasi teks yang berisikan teks Materi 1 Himpuanan Bagian

b) Materi $2:$ Berisikan teori-teori tentang teori-teori yang berhubungan dengan himpunan bagian.

c) Tombol back: Merupakan tombol untuk kembali ke materi sebelumnya d) Tombol volume : Merupakan Tombol untuk suara.

e) Next : Materi selanjutnya

\section{Rancangan Menu Materi 3}

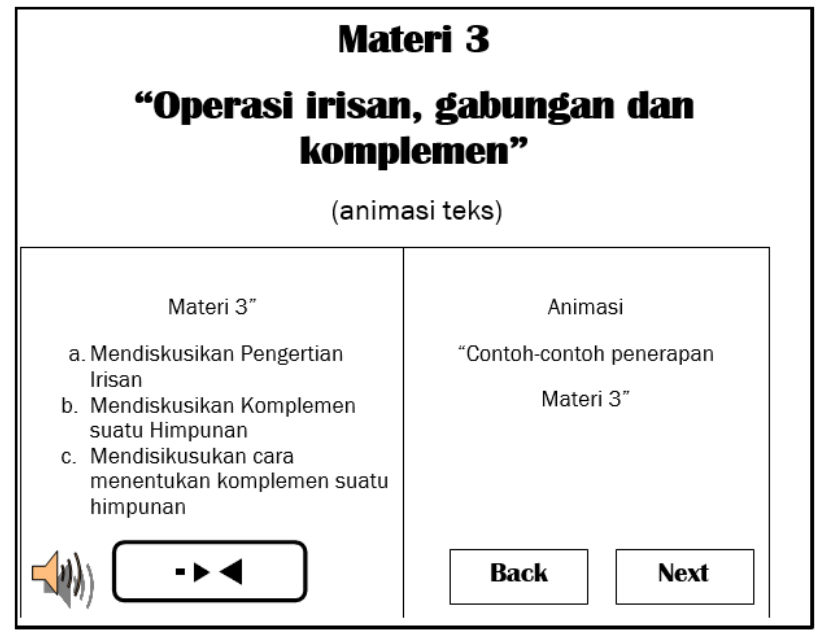

Gambar 6. Rancangan Menu Materi 3

Keterangan:

a) Animasi Teks : Animasi teks yang berisikan teks Materi 1 Operasi Irisan

b) Materi 3 : Berisikan teori-teori tentang teori-teori yang berhubungan dengan Operasi Irisan.

c) Tombol back: Merupakan tombol untuk kembali ke materi sebelumnya

d) Tombol volume : Merupakan Tombol untuk suara.

e) Next : Materi selanjutnya

\section{Rancangan Menu Materi 4}

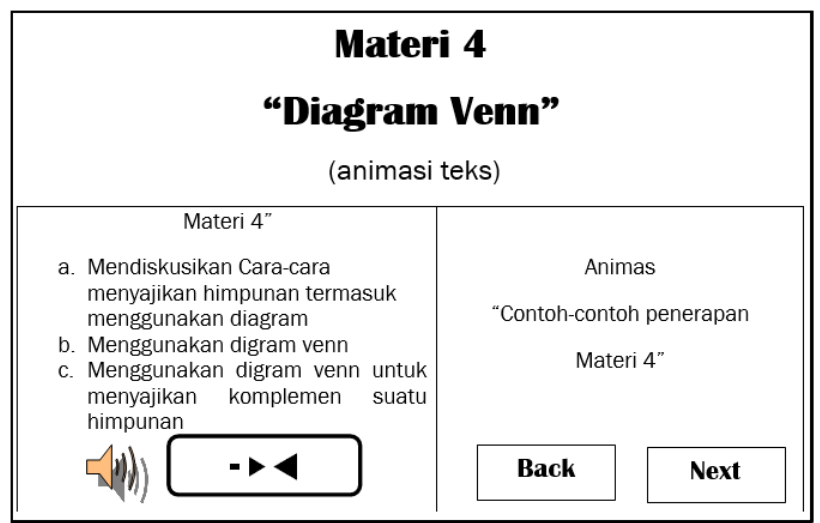

Gambar 7. Rancangan Menu Materi 4

Keterangan:

a) Animasi Teks : Animasi teks yang berisikan teks Materi 4 Diagram Venn

b) Materi 4 : Berisikan teori-teori tentang teori-teori yang berhubungan dengan Diagram Venn. 
c) Tombol back: Merupakan tombol untuk kembali materi sebelumnya

d) Tombol volume : Merupakan Tombol untuk suara.

e) Next : Materi selanjutnya

\section{Rancangan Menu Materi 5}

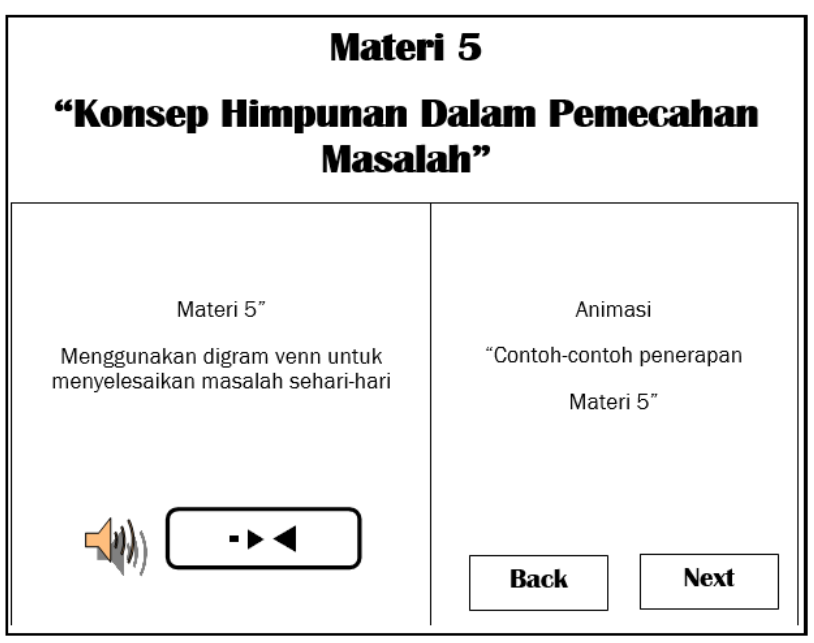

Gambar 8. Rancangan Menu Materi 5

Keterangan:

a) Animasi Teks : Animasi teks yang berisikan teks Materi 5 Himpuanan Bagian

b) Materi 5 : Berisikan teori-teori tentang teori-teori yang berhubungan dengan Konsep Himpunan dalam pemecahan masalah.

c) Tombol back: Merupakan tombol untuk kembali ke materi sebelumnya

d) Tombol volume : Merupakan Tombol untuk suara.

e) Next : Materi selanjutnya

\section{Rancangan Menu Latihan}

Sebelum menjawab soal-soal latihan himpunan, siswa terlebih dahulu mengentri namanya gar nanti dapat diketahui skor yang dieroleh. Adapun rancangan tampilan halaman latihan dapat dilihat sebagai berikut:

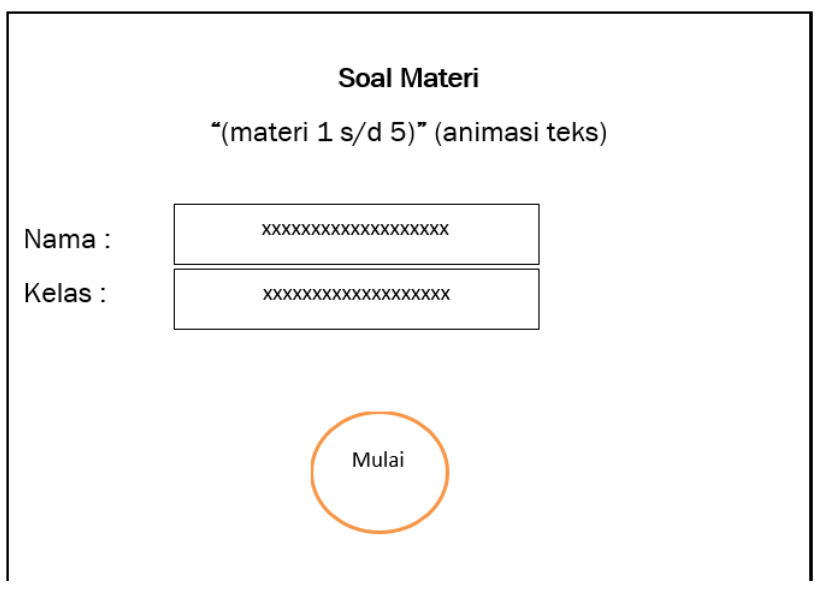

Gambar 9. Rancangan Menu Latihan
Rancangan Menu Latihan Soal untuk Setiap Materi

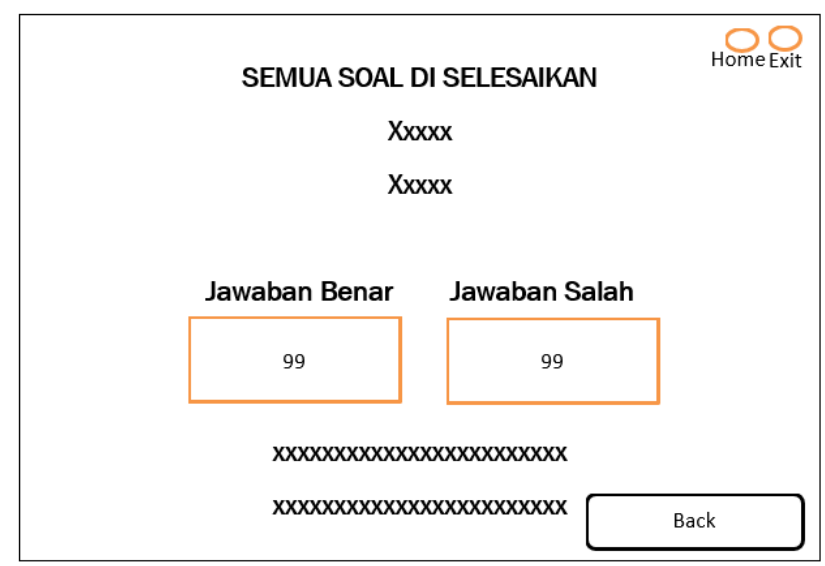

Gambar 10. Rancangan Menu Latihan Soal untuk Setiap Materi

Keterangan:

a) Animasi Teks : Animasi teks yang berisikan teks Latihan soal dari setiap materi yang dipilih.

b) Tombol $1:$ Merupakan tombol untuk kembali menu soal materi

c) Tombol a,b,c dan d : Merupakan pilihan jawaban soal yang bersangkutan.

d) Setelah dijawab maka dilanjutkan kesoal berikutnya sampai siswa selesai mengerjakan semua soal pada materi yang bersangkutan.

Rancangan Halaman Hasil atau Nilai Latihan

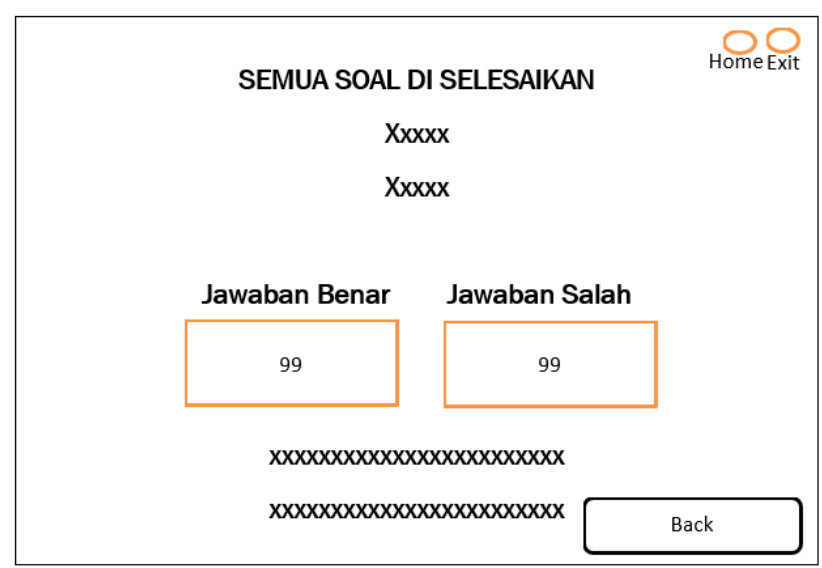

Gambar 11.Rancangan Menu Halaman Hasil Latihn

Keterangan:

a) Nilai Anda : merupakan teks yeng memberitahukan tentang hasil dari pada latihan yang dilakukan.

b) Teks 1 : Berisikan nama sesuai dengan nama yang di inputkan ketika memulai pengerjaan soalsioal latihan

c) Nilai : berisikan nilai dari hasil pengerjaan soal yang nilainya kelipatan 20 nilai minimal 0 dan maximal 100. 
d) Keterangan : Berisikan informasi tentang tingkat keberhasilan pengerjaan soal atau penguasaan Materi yaitu :

e) Jika Nilai kecil dari 50 maka keterangan : Anda Perlu Banyak Belajar Lagi

f) Jika Nilai besar atau sama dengan 50 maka Keterangannya : Selamat Anda Sukses Menguasai Materi.

g) Tombol Back: Berfungsi untuk kembali kemenu sebelumnya.

h) Tombol Home : Berfungsi untuk kembali ke Menu Utama

i) Tombol Exit : Berfungsi untuk keluar dari aplikasi.

\section{D) Pengujian Sistem}

Pengujian dalam penelitian ini dilaksanakan oleh pihak user atau pengguna, sedangkan untuk metode pengujian yang digunakan adalah pengujian balack box. Pengujian black box adalah pengujian aspek fundamental sistem tanpa memperhatikan struktur logika internal perangkat lunak. Metode ini digunakan untuk mengetahui apakah perangkat lunak berfungsi dengan benar. Pengujian black box merupakan metode perancangan data uji yang didasarkan pada sepesifikasi perangkat lunak yang dibuat.

\section{PEMBAHASAN}

A) Hasil Program dan Pembahasan

Konsep himpunan diagram Venn pada SMP Neeri 07 Bengkulu ini diimpelementasikan dengan menggunakan Macromedia Flash 8.0Aplikasi ini terdiri dari menu-menu, antaralain sebagai berikut:

\section{1) Tampilan Halaman Awal}

Halaman ini merupakan tampilan awal sistem. Pada halaman ini disediakan button "Click To" untuk masuk ke menu home. Adapun tampilan halaman awal dapat dilihat pada Gambar berikut.

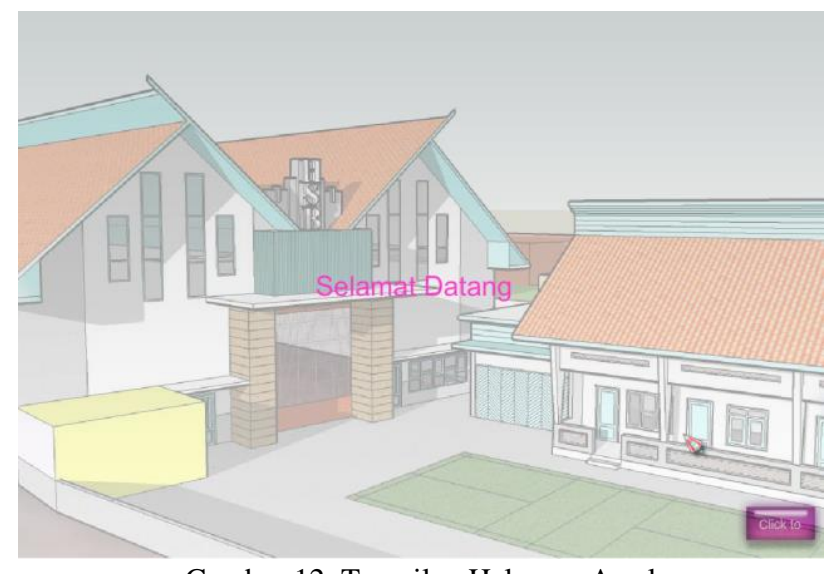

Gambar 12. Tampilan Halaman Awal

\section{2) Tampilan Halaman Home}

Pada halaman ini terdapat enam button. Yaitu 5 butto materi dan 1 button latihan. Yaitu terdiri dari materi 1, materi 2, materi 3 , materi 4 dan materi 5 . Adapun tampilan halaman home dapat dilihat pada Gambar berikut.

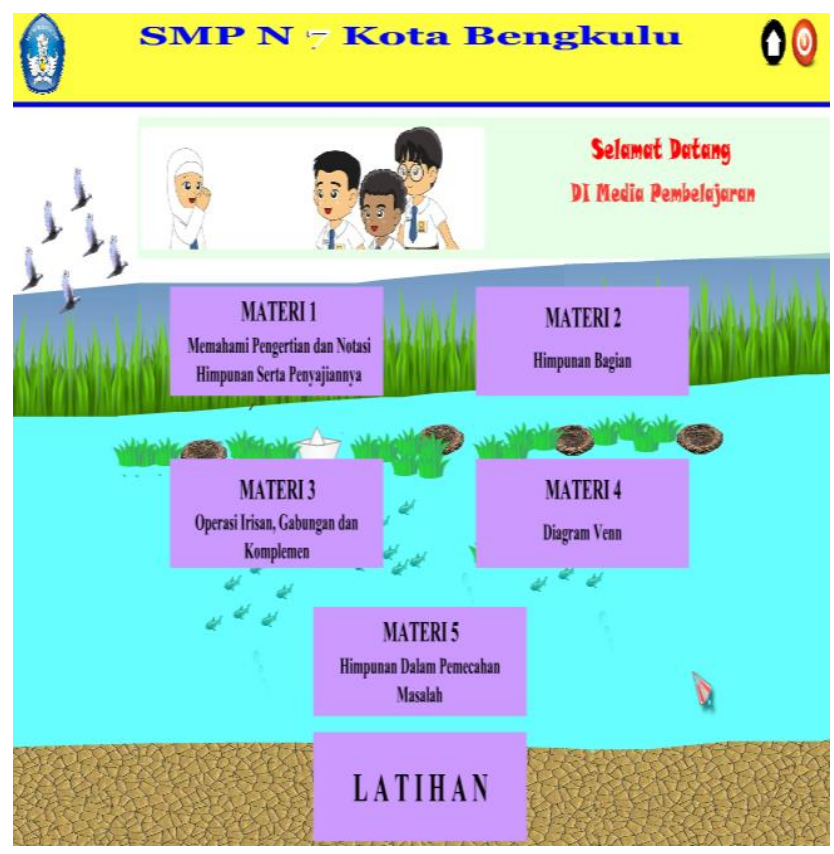

Gambar 13. Tampilan Halaman Home

\section{3) Tampilan Halaman Materi Memahami \\ Pengertian dan Notasi Himpunan serta \\ Penyajiannya}

Pada halaman ini berisi materi tentang memahami pengertian dan notasi himpunan serta penyajiannya. Pada halaman ini disertai juga dengan tombol "Back" untuk kembali ke menu home dan tombol "Next" untuk tampilan meteri berikutnya. Tampilan halaman materi ini dapat dilihat pada gambar berikut:

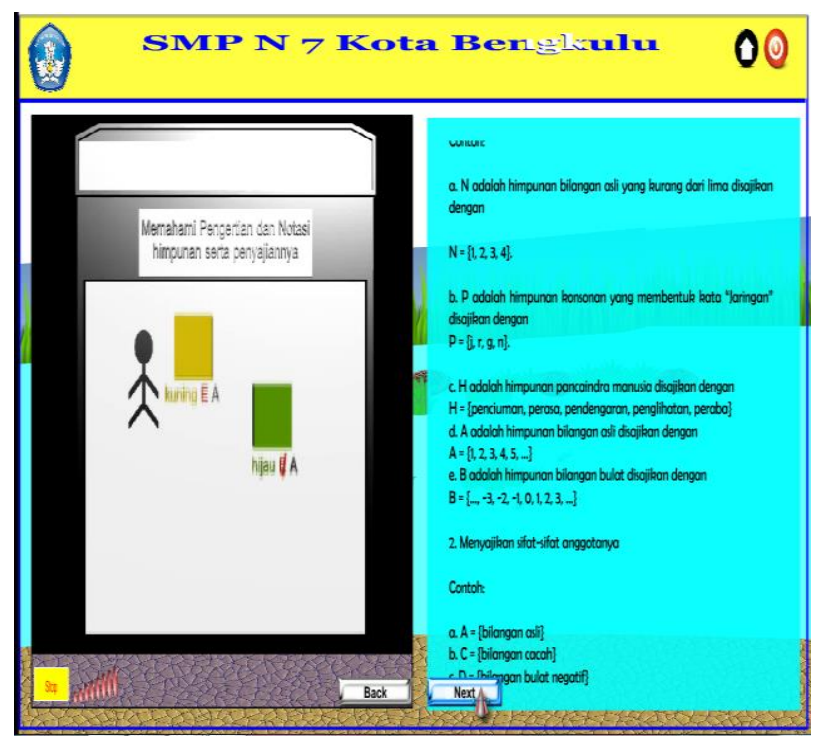

Gambar 14. Tampilan Halaman Materi Memahami Pengertian dan Notasi Himpunan serta Penyajiannya 


\section{4) Tampilan Halaman Materi Himpunan Bagian}

Pada halaman ini berisi materi tentang himpunan bagian. Pada halaman ini disertai juga dengan tombol "Back" untuk kembali ke menu materi sebelumnya dan tombol "Next" untuk tampilan meteri berikutnya. Tampilan halaman materi ini dapat dilihat pada gambar berikut:

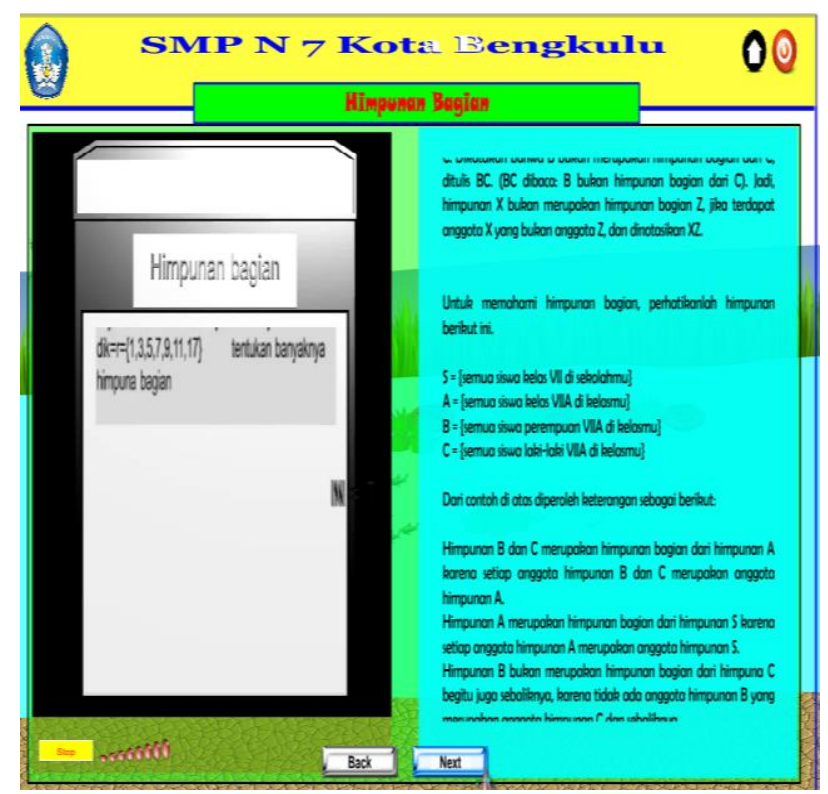

Gambar 15. Tampilan Halaman Materi Himpunan Bagian

\section{5) Tampilan Halaman Materi Operasi Irisan, Gabungan dan Komplemen}

Pada halaman ini berisi materi tentang operasi irisan, gabungan dan komplemen. Pada halaman ini disertai juga dengan tombol "Back" untuk kembali ke menu materi sebelumnya dan tombol "Next" untuk tampilan meteri berikutnya. Tampilan halaman materi ini dapat dilihat pada gambar berikut:

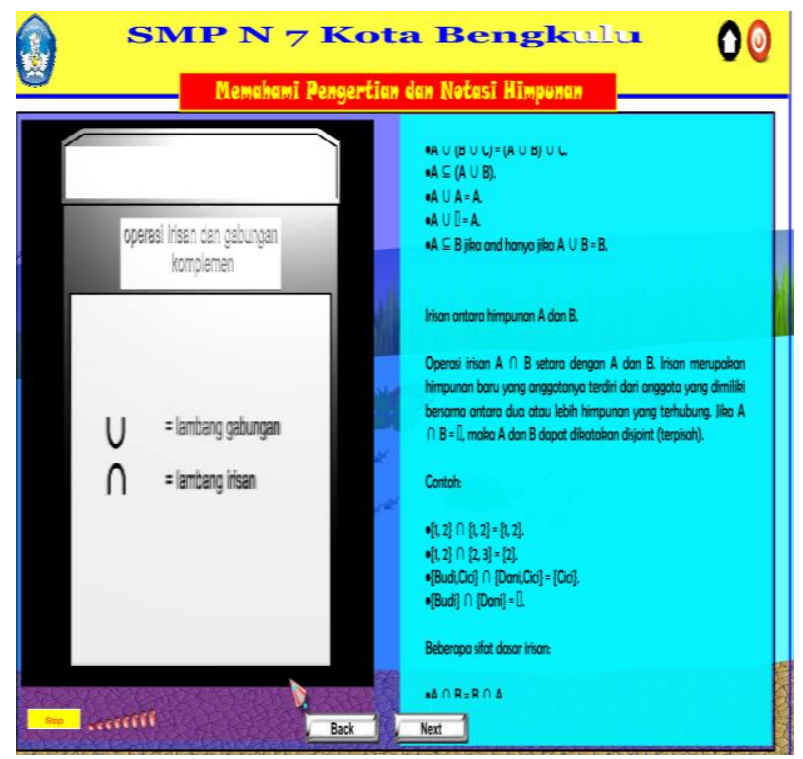

Gambar 16. Tampilan Halaman Materi Operasi Irisan, Gabungan dan Komplemen

\section{6) Tampilan Halaman Materi Diagram Venn}

Pada halaman ini berisi materi tentang diagram Venn. Pada halaman ini disertai juga dengan tombol "Back" untuk kembali ke menu materi sebelumnya dan tombol "Next" untuk tampilan meteri berikutnya. Tampilan halaman materi ini dapat dilihat pada gambar berikut:

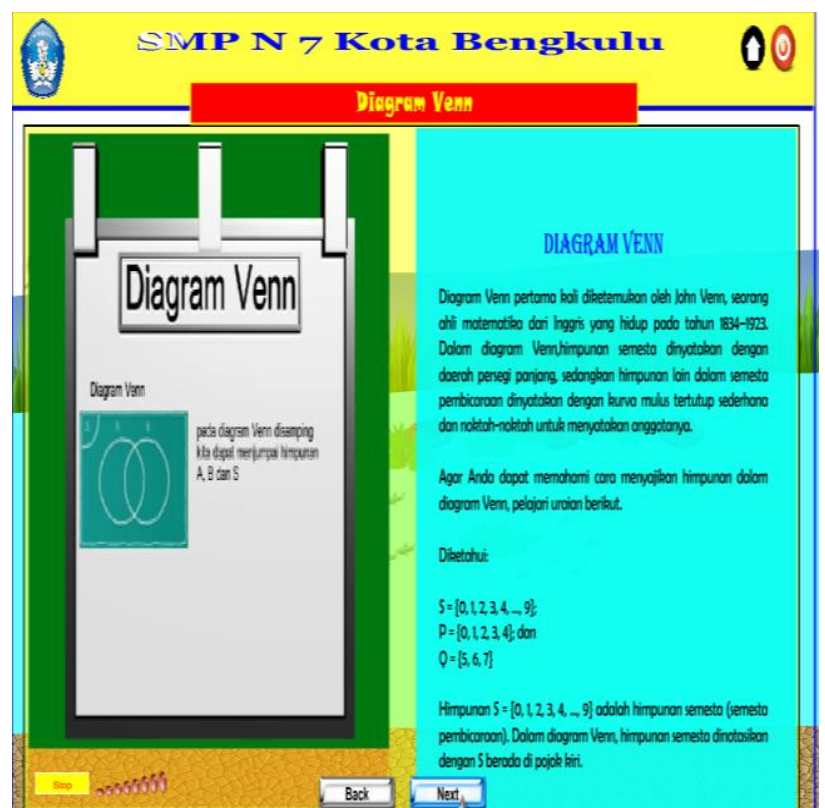

Gambar 17. Tampilan Halaman Materi Diagram Venn

\section{7) Tampilan Halaman Materi Himpunan Dalam \\ Pemecahan Masalah}

Pada halaman ini berisi materi tentang himpunan dalam pemecahan masalah. Pada halaman ini disertai juga dengan tombol "Back" untuk kembali ke menu materi sebelumnya dan tombol "Next" untuk tampilan meteri berikutnya. Tampilan halaman materi ini dapat dilihat pada gambar berikut:

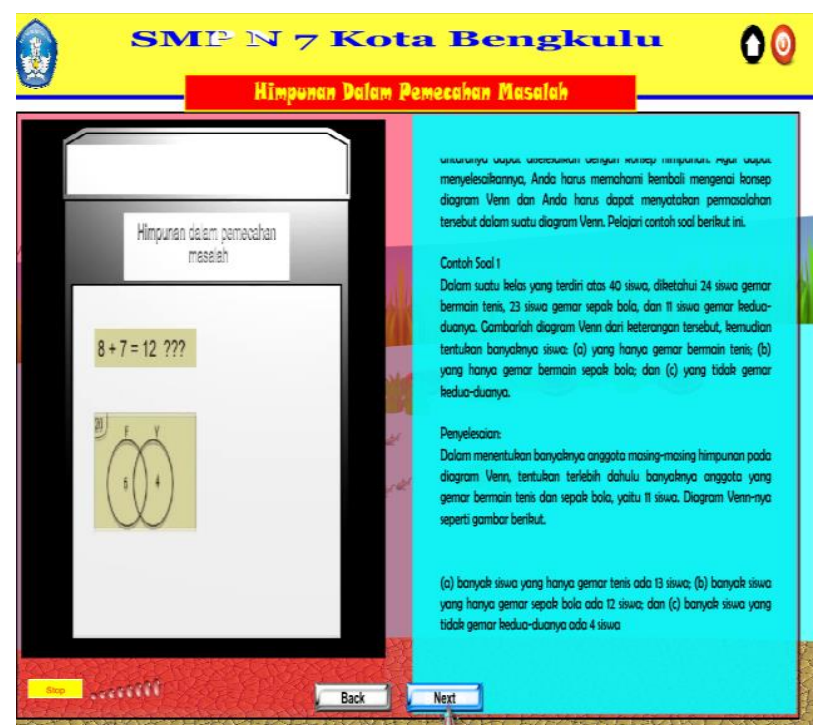

Gambar 18. Tampilan Halaman Materi Himpunan Dalam Pemecahan Masalah 


\section{8) Tampilan Halaman Latihan}

Tampilan halaman latihan merupakan halaman yang menyediakan latihan-latihan soal seputar diaran venn. Sebelum menjawab soal-soal tersebut, terlebih dahulu masukkan nama siswa. Form untuk memasukkan nama siswa adalah sebagai berikut:

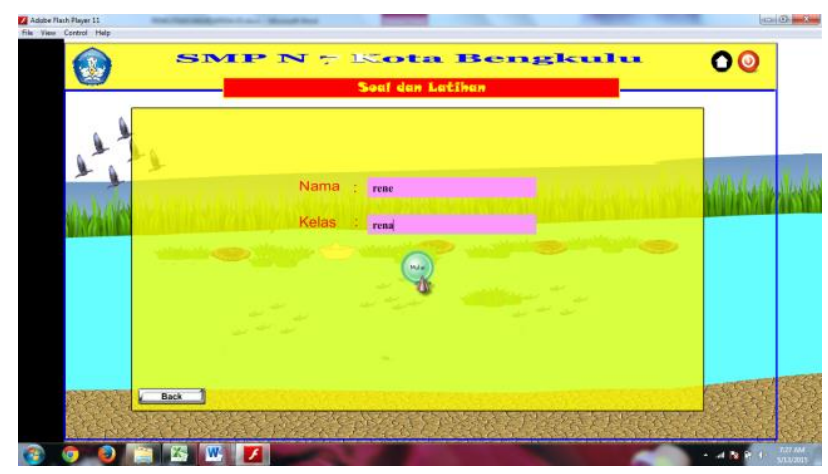

Gambar 19. Tampilan Halaman Input Nama

Kemudian setelah nama dimasukkan maka klik butoon "mulai". Maka akan ditampilkan halaman soal seperti pada gambar berikut:

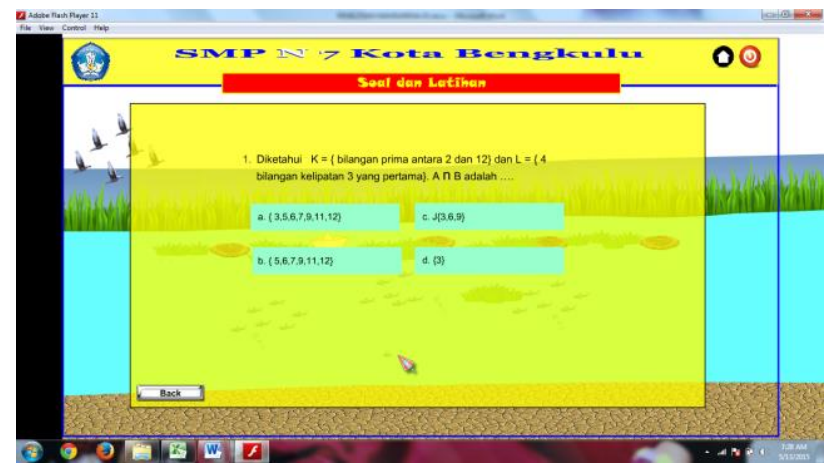

Gambar 20. Tampilan Halaman Tampilan Soal

Kemudian setelah menjawab semua soal maka akan ditampilkan score penilaian benar dan salah dalam menjawab soal seperti pada gambar berikut:

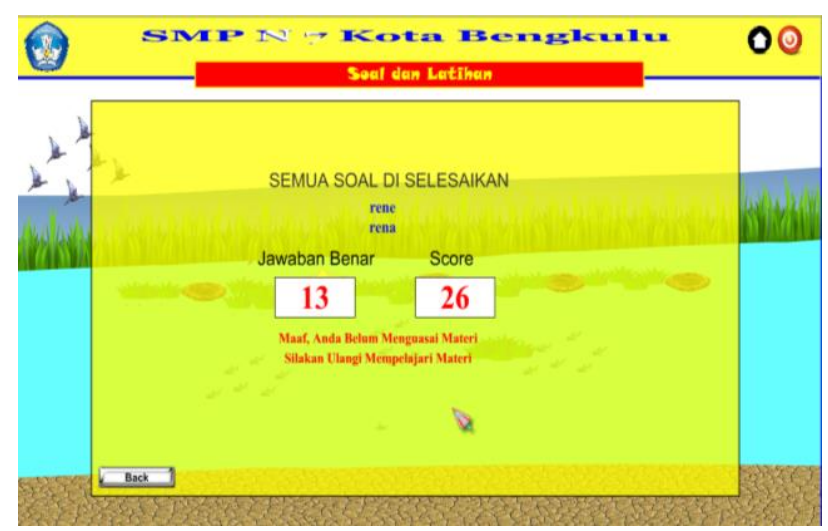

Gambar 21. Tampilan Halaman Score

\section{9) Tampilan Halaman Keluar sistem}

Halaman ini digunakan untuk keluar dari sisstem. Adapun tampilan halaman keluar dapat dilihat pada gambar berikut.

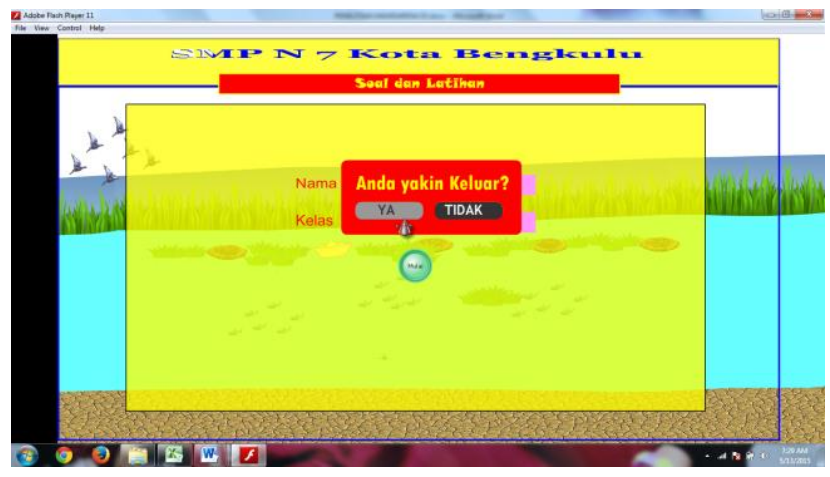

Gambar 22. Tampilan Halaman Keluar Sistem

\section{B) Hasil Pengujian}

Pengujian dalam penelitian ini dilaksanakan oleh pihak user atau pengguna, sedangkan untuk metode pengujian yang digunakan adalah pengujian black box. Pengujian black box adalah pengujian aspek fundamental sistem tanpa memperhatikan struktur logika internal perangkat lunak. Metode ini digunakan untuk mengetahui apakah perangkat lunak berfungsi dengan benar. Pengujian black box merupakan metode perancangan data uji yang didasarkan pada sepesifikasi perangkat lunak yang dibuat. Adapun pengujian Black Box yang dilakukan adalah sebagai berikut:

\section{1) Pengujian Menu}

Tabel 1. Prngujian Menu

\begin{tabular}{|l|l|l|l|l|}
\hline No & $\begin{array}{l}\text { Fungsi } \\
\text { yang di } \\
\text { Uji }\end{array}$ & $\begin{array}{l}\text { Cara } \\
\text { Pengujian }\end{array}$ & $\begin{array}{l}\text { Hasil yang } \\
\text { Diharapkan }\end{array}$ & $\begin{array}{l}\text { Hasil } \\
\text { Pengujian }\end{array}$ \\
\hline 1 & $\begin{array}{l}\text { Halaman } \\
\text { Intro }\end{array}$ & $\begin{array}{l}\text { Menjalankan } \\
\text { Sistem }\end{array}$ & $\begin{array}{l}\text { Menampilkan } \\
\text { halaman intro } \\
\text { berupa } \\
\text { ucapan } \\
\text { selamat } \\
\text { datang dan } \\
\text { animasi } \\
\text { gambar } \\
\text { sekolah }\end{array}$ & OK \\
\hline 2 & $\begin{array}{l}\text { Menu } \\
\text { Home }\end{array}$ & $\begin{array}{l}\text { Mengklik } \\
\text { button } \\
\text { "Click To" } \\
\text { di halaman } \\
\text { intro }\end{array}$ & $\begin{array}{l}\text { Setelah } \\
\text { mengklik } \\
\text { button “click } \\
\text { TO" di } \\
\text { halaman intro } \\
\text { maka akan } \\
\text { muncul } \\
\text { halaman } \\
\text { home }\end{array}$ & OK \\
& & $\begin{array}{l}\text { Terdapatnya } \\
\text { materi } \\
\text { tentang } \\
\text { pengertian }\end{array}$ & OK \\
\hline 3 & Materi 1 & $\begin{array}{l}\text { Mengklik } \\
\text { button " } \\
\text { Materi 1" } \\
\text { pada }\end{array}$ & \\
\hline
\end{tabular}




\begin{tabular}{|c|c|c|c|c|}
\hline No & $\begin{array}{l}\text { Fungsi } \\
\text { yang di } \\
\text { Uji }\end{array}$ & $\begin{array}{l}\text { Cara } \\
\text { Pengujian }\end{array}$ & $\begin{array}{l}\text { Hasil yang } \\
\text { Diharapkan }\end{array}$ & $\begin{array}{l}\text { Hasil } \\
\text { Pengujian }\end{array}$ \\
\hline & & $\begin{array}{l}\text { halaman } \\
\text { home }\end{array}$ & $\begin{array}{l}\text { dan notasi } \\
\text { himpunan }\end{array}$ & \\
\hline 4 & Materi 2 & $\begin{array}{l}\text { Mengklik } \\
\text { button “" } \\
\text { Materi 2" } \\
\text { pada } \\
\text { halaman } \\
\text { home }\end{array}$ & $\begin{array}{l}\text { Terdapatnya } \\
\text { materi } \\
\text { tentang } \\
\text { Himpunan } \\
\text { bagian }\end{array}$ & OK \\
\hline 5 & Materi 3 & $\begin{array}{l}\text { Mengklik } \\
\text { button “" } \\
\text { Materi 3" } \\
\text { pada } \\
\text { halaman } \\
\text { home }\end{array}$ & $\begin{array}{l}\text { Terdapatnya } \\
\text { materi } \\
\text { tentang Irisan, } \\
\text { gabungan, } \\
\text { Kurang dan } \\
\text { Komplement }\end{array}$ & OK \\
\hline 6 & Materi 4 & $\begin{array}{l}\text { Mengklik } \\
\text { button “" } \\
\text { Materi 4" } \\
\text { pada } \\
\text { halaman } \\
\text { home }\end{array}$ & $\begin{array}{l}\text { Terdapatnya } \\
\text { materi } \\
\text { tentang } \\
\text { Diagram } \\
\text { Venn }\end{array}$ & OK \\
\hline 7 & Materi 5 & $\begin{array}{l}\text { Mengklik } \\
\text { button “" } \\
\text { Materi 5" } \\
\text { pada } \\
\text { halaman } \\
\text { home }\end{array}$ & $\begin{array}{l}\text { Terdapatnya } \\
\text { materi } \\
\text { tentang } \\
\text { Himpunan } \\
\text { dalam } \\
\text { pemecahan } \\
\text { masalah }\end{array}$ & OK \\
\hline 8 & Latihan & $\begin{array}{l}\text { Mengklik } \\
\text { button “" } \\
\text { Latihan" } \\
\text { pada } \\
\text { halaman } \\
\text { home }\end{array}$ & $\begin{array}{l}\text { Terdapatnya } \\
\text { soal latihan } \\
\text { mengenai } \\
\text { materi } 1 \\
\text { sampai } \\
\text { dengan materi } \\
5\end{array}$ & OK \\
\hline
\end{tabular}

Berdasarkan hasil pengujian dengan kasus uji sample di atas dapat ditarik kesimpulan bahwa secara fungsional perangkat lunak sudah sesuai dengan yang diharapkan.

\section{2) Pengujian Menggunakan Kuisioner}

Pengujian sistem Konsep Himpunan dan Diagram Venn pada SMP Negeri 07 Bengkulu berbasis Multimedia dilakukan dengan menyebarkan kuisoner kepada 5 orang guru dan 1 orang 5 siswa di SMP Negeri 07 Kota Bengkulu. Kemudian hasil kuisioner tersebut di olah kembali sehingga menghasilkan sebuah informasi kelayakan pengujian sistemmultimedia ini. Adapun hasil pengolahan kuisioner tersebut adalah sebagai berikut:

\section{Hasil Pengolahan Responden Guru}

Berdasarkan data hasil kusioner dengan responden 5 orang guru di SMP Negeri 07 Kota Bengkulu, maka prosentase masing masing jawaban di cari dengan menggunakan rumus :

$$
\mathrm{Y}=\mathrm{P} / \mathrm{Q} * 100 \%
$$

Keterangan :

$\mathrm{P}=$ Banyaknya jawaban responden tiap soal.

$\mathrm{Q}=$ Jumlah responden

$\mathrm{Y}=$ Nilai persentase

Hasil yang didapatkan dapat dilihat pada table berikut.

Tabel 2. Hasil Jawaban Responden Guru

\begin{tabular}{|l|l|l|l|l|l|}
\hline No & Pernyataan & SS & S & KS & TS \\
\hline 1 & $\begin{array}{l}\text { Aplikasi ini dapat membantu } \\
\text { mempercepat proses belajar } \\
\text { mengajar tentang pelajaran } \\
\text { himpunan dan diagram venn } \\
\text { mata pelajaran matematika pada } \\
\text { SMP Negeri 07 Kota Bengkulu }\end{array}$ & 3 & 2 & 0 & 0 \\
\hline 2 & $\begin{array}{l}\text { Dengan adanya aplikasi ini kami } \\
\text { merasa lebih mudah dalam } \\
\text { memberikan materi kepada } \\
\text { siswa }\end{array}$ & 4 & 1 & 0 & 0 \\
\hline 3 & $\begin{array}{l}\text { Media pembelajaran ini layak } \\
\text { untuk digunakan sebagai alat } \\
\text { mediasi untuk mata pelajaran } \\
\text { matematika }\end{array}$ & 2 & 3 & 0 & 0 \\
\hline 4 & $\begin{array}{l}\text { Media pembelajaran matematika } \\
\text { tentang himpunan dan diagram } \\
\text { venn ini telah sesuai dengan } \\
\text { kurikulum yang ada }\end{array}$ & 1 & 4 & 0 & 0 \\
\hline 5 & $\begin{array}{l}\text { Kami sebagai guru mendapat } \\
\text { kemudahan pada saat } \\
\text { memberikan materi tentang } \\
\text { pelajaran himpunan dan diagram } \\
\text { venn }\end{array}$ & 4 & 1 & 0 & 0 \\
\hline
\end{tabular}

Berdasarkan hasil jawaban responden di atas, maka persentase dan grafik yang didapatkan dapat dilihat pada table dan gambar berikut:

Tabel 3. Persentase Hasil Jawaban Responden Guru

\begin{tabular}{|l|l|l|l|l|}
\hline Pertanyaan & SS & S & KS & TS \\
\hline Pertanyaan 1 & $60 \%$ & $40 \%$ & 0 & 0 \\
\hline Pertanyaan 2 & $80 \%$ & $20 \%$ & 0 & 0 \\
\hline Pertanyaan 3 & $40 \%$ & $60 \%$ & 0 & 0 \\
\hline Pertanyaan 4 & $20 \%$ & $80 \%$ & 0 & 0 \\
\hline Pertanyaan 5 & $80 \%$ & $20 \%$ & 0 & 0 \\
\hline
\end{tabular}

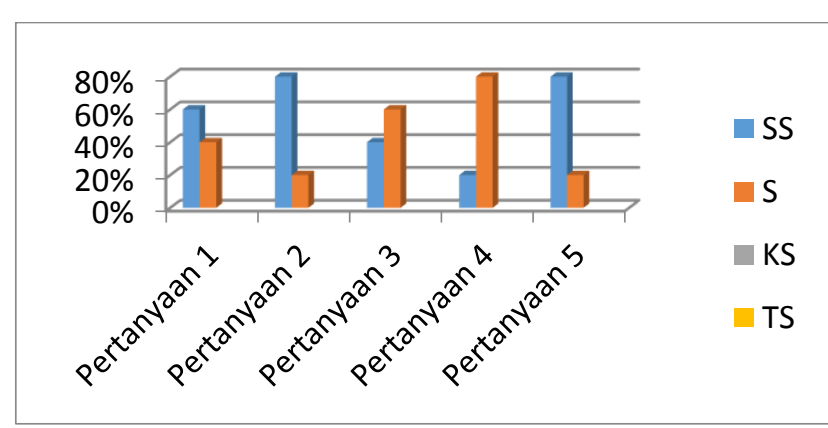

Gambar 23. Grafik Hasil Jawaban Responden Guru Hasil Pengolahan Responden Siswa 
Berdasarkan data hasil kusioner dengan responden 15 orang siswa kelas VIII di SMP Negeri 07 Kota Bengkulu, maka persentase masing masing jawaban di cari dengan menggunakan rumus :

$$
\mathrm{Y}=\mathrm{P} / \mathrm{Q} * 100 \%
$$

Keterangan :

$\mathrm{P}=$ Banyaknya jawaban responden tiap soal.

$\mathrm{Q}=$ Jumlah responden

$\mathrm{Y}=$ Nilai persentase

Hasil yang didapatkan dapat dilihat pada table berikut.

Tabel 4. Persentasee Hasil Jawaban Kuisioner

\begin{tabular}{|c|c|c|c|c|c|}
\hline No & Pernyataan & SS & $\mathbf{S}$ & $\mathbf{K S}$ & TS \\
\hline 1 & $\begin{array}{l}\text { Dengan adanya aplikasi ini } \\
\text { saya lebih mudah untuk } \\
\text { memahami mata pelajaran } \\
\text { matematika khususnya konsep } \\
\text { himpunan dan diagram venn } \\
\end{array}$ & 10 & 5 & & \\
\hline 2 & $\begin{array}{l}\text { Aplikasi ini dapat membantu } \\
\text { saya dalam memahami konsep } \\
\text { himpunan dan diagram venn }\end{array}$ & 8 & 7 & & \\
\hline 3 & $\begin{array}{l}\text { Aplikasi tentang konsep } \\
\text { himpunan dan diagram venn ini } \\
\text { menarik }\end{array}$ & 9 & 6 & & \\
\hline 4 & $\begin{array}{l}\text { Pada aplikasi latihannya saya } \\
\text { bisa langsung mengetahui nilai } \\
\text { dari hasil latihan }\end{array}$ & 11 & 4 & & \\
\hline 5 & $\begin{array}{l}\text { Dengan aplikasi ini saya bisa } \\
\text { belajar sendiri }\end{array}$ & 10 & 5 & & \\
\hline 6 & $\begin{array}{l}\text { Dengan aplikasi ini saya bisa } \\
\text { mengerjakan soal-soal sendiri }\end{array}$ & 12 & 3 & & \\
\hline 7 & $\begin{array}{l}\text { Dengan aplikasi ini saya } \\
\text { menjadi suka belajar } \\
\text { matematika khususnya } \\
\text { pelajaran himpunan dan } \\
\text { diagram venn } \\
\end{array}$ & 12 & 3 & & \\
\hline 8 & $\begin{array}{l}\text { Dengan aplikasi ini saya } \\
\text { menjadi tau kemampuan } \\
\text { belajar saya }\end{array}$ & 7 & 8 & & \\
\hline 9 & $\begin{array}{l}\text { Dengan aplikasi ini saya } \\
\text { menjadi mudah mengulang } \\
\text { kembali pelajaran }\end{array}$ & 5 & 10 & & \\
\hline 10 & $\begin{array}{l}\text { Saya menyukai aplikasi ini } \\
\text { sebagai alat bantu } \\
\text { pembelajaran matematika } \\
\text { khususnya pelajaran himpunan } \\
\text { dan diagram venn }\end{array}$ & 13 & 2 & & \\
\hline
\end{tabular}

Berdasarkan hasil jawaban responden di atas, maka persentase dan grafik yang didapatkan dapat dilihat pada table dan gambar berikut:

Tabel 5. Hasil Jawaban Responden Siswa

\begin{tabular}{|l|l|l|l|l|}
\hline Pertanyaan & SS & S & KS & TS \\
\hline Pertanyaan 1 & 66.7 & 33.3 & $0 \%$ & $0 \%$ \\
\hline Pertanyaan 2 & 53.3 & 46.7 & $0 \%$ & $0 \%$ \\
\hline Pertanyaan 3 & 60.0 & 40.0 & $0 \%$ & $0 \%$ \\
\hline Pertanyaan 4 & 73.3 & 26.7 & $0 \%$ & $0 \%$ \\
\hline Pertanyaan 5 & 66.7 & 33.3 & $0 \%$ & $0 \%$ \\
\hline
\end{tabular}

\begin{tabular}{|l|l|l|l|l|} 
Pertanyaan 6 & 80.0 & 20.0 & $0 \%$ & $0 \%$ \\
\hline Pertanyaan 7 & 80.0 & 20.0 & $0 \%$ & $0 \%$ \\
\hline Pertanyaan 8 & 46.7 & 53.3 & $0 \%$ & $0 \%$ \\
\hline Pertanyaan 9 & 33.3 & 66.7 & $0 \%$ & $0 \%$ \\
\hline Pertanyaan 10 & 86.7 & 13.3 & $0 \%$ & $0 \%$ \\
\hline
\end{tabular}

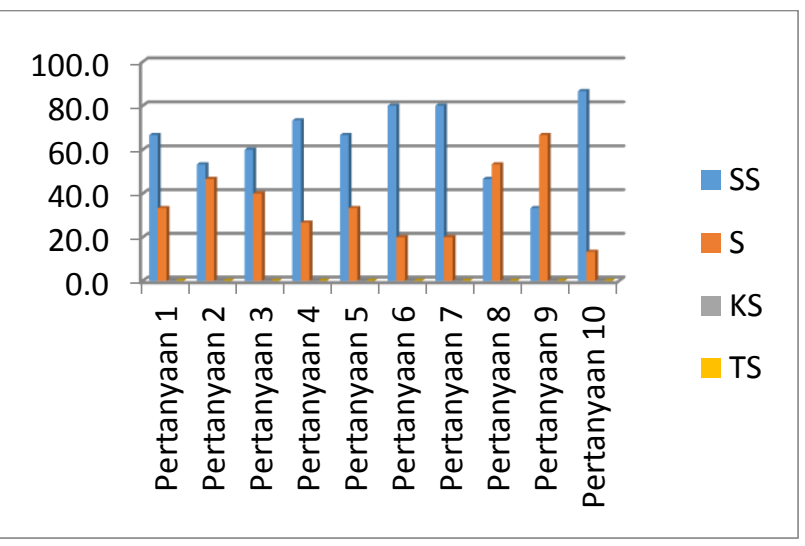

Gambar 24. Grafik Hasil Jawaban Responden Siswa

Berdasarkan hasil jawaban responden semua resonden di atas semua responden menjawab sangat setuju dan setuju. Tidak ada responden yang menjawab kurang setuju dan tidak setuju. Sehingga dapat disimpulkan bahwasanya sistem sudah layak untuk digunakan.

\section{PENUTUP}

\section{A) Kesimpulan}

Bahasa pemrograman Macromedia Flash 8.0 dapat memberikan kemudahan dalam pembuatan media Flash untuk pembuatan aplikasi Multimedia Konsep Himpunan dan Diagram Venn pada SMP Negeri 07 Bengkulu

Pembuatan media Flash n aplikasi Multimedia Konsep Himpunan dan Diagram Venn pada SMP Negeri 07 Bengkulu dapat memberikan kemudahan dalam proses belajar mengajar tentang Konsep Himpunan dan Diagram Venn pada SMP Negeri 07 Bengkulu

\section{B) Saran-saran}

Agar sistem yang diusulkan dapat digunakan lebih optimal dan dapat berjalan sesuai dengan yang diharapkan, maka ada beberapa saran yang dapat dijadikan bahan pertimbangan untuk SMP Negeri 07 Bengkulu Bengkulu, yaitu:

Sistem yang dibangun pada intinya hanya sebatas sistem aplikasi multimedia tentang media Flash untuk pembuatan aplikasi Multimedia Konsep Himpunan dan Diagram Venn pada SMP Negeri 07 Bengkulu. Sehingga kedepannya diharapkan adanya pengembangan lagi untuk sistem yang lebih luas 
cakupannya seperti pengujian sistem secara online dan lain sebagainya.

Diperlukan maintenace terhadap sistem yang telah dibuat, supaya dapat digunakan secara berkelanjutan selama kebutuhan terhadap informasi yang dibutuhkan.

\section{DAFTAR PUSTAKA}

Arsyad, Azhar. 2010. Media Pembelajaran. Jakarta: PT Raja Grafindo Persada

Arsyad. 2012. Media Pembelajaran. Jakarta: Raja GrafindoPersada

Dr. Azhar Susanto, MBus, Ak. 2004. Sistem Informasi Manajemen Konsep dan Pengembangannya. Lingga Jaya. Bandung.

Kusuma, Afandi. 2009. Aditif Makanan. Jakarta: Raja GrafindoPersada

Nugroho, Bunafit . 2008. Latihan membuat aplikasi Web PHP dan MySQL dengan Dreamweaver, Yogyakarta:Penerbit Gramedia.

Rusman, dkk. 2011. Pembelajaran Berbasis Teknologi Informasi dan Komunikasi.

Jakarta: PT RajaGrafindo Persada

Sudirman. 2011. Interaksi Dan Motivasi Belajar Mengajar. Jakarta: PT Raja Grafindo Persada 